\section{Dietary Supplementation with Fermented Radix astragalus-ginkgo Leaves Improves Antioxidant Capacity and Meat Quality in Broilers}

\author{
Xuhui Zhang ${ }^{1}$, Zhiyuan Sun ${ }^{2}$, Jinfeng Cai ${ }^{1}$, Guibin Wang ${ }^{1}$, Zunling Zhu ${ }^{1}$, \\ Linguo Zhao ${ }^{3}$ and Fuliang Cao,* \\ ${ }^{1}$ Co-Innovation Center for Sustainable Forestry in Southern China, Nanjing Forestry \\ University, Longpan Road, Nanjing 210037, P.R. China \\ ${ }^{2}$ Department of Animal Husbandry and Veterinary Science, Jiangsu Polytechnic College \\ of Agriculture and Forestry, Jurong Jiangsu 212400, P.R. China \\ ${ }^{3}$ College of Chemical Engineering, Nanjing Forestry University, Nanjing, China
}

Xuhui Zhang and Zhiyuan Sun contributed equally to this work and are considered as co-first authors.

\begin{abstract}
A B S T R A C T
The objective of this study was to compare the effect of non-fermented (NF) and fermented Radix astragali-ginkgo leaves (FR) products produced by fermentation using Aspergillus niger on growth, antioxidant capacity and meat quality of broilers. Three hundred day-old commercial Arbor Acres (AA) broiler chicks were randomly allocated into 5 dietary treatments including five variations: control group, fed with the basal diets; NF group, the addition of $3 \mathrm{~g} / \mathrm{kg}$ NF products; FR1, FR2 and FR3 groups, addition of FR products $1 \mathrm{~g} / \mathrm{kg}, 3 \mathrm{~g} / \mathrm{kg}$ and $6 \mathrm{~g} / \mathrm{kg}$, respectively. There was no difference in body weight gain, feed intake and feed intake/gain ratio between treatments. Compared with the control group, the percentage of the abdominal fat, sarcous fat and lactic acid (LD) for FR groups were significantly decreased. Birds had significantly higher water holding capacity (WHC) when they were provided with the FR3 diet. Moreover, serum glutathione (GSH) and $\alpha$-tocopherol $(\alpha-\mathrm{TOH})$ contents in the FR groups were increased, while, levels of total cholesterol (TC), malondialdehyde (MDA) in serum and hepatic reactive oxygen species (ROS) in FR groups were significantly decreased compared with the control or NF group at $42 \mathrm{~d}$ of age. Furthermore, serum total superoxide dismutase (T-SOD) activity of birds from group FR3 was significantly increased (42d) compared with NF group. Additionally, the expression of antioxidant enzyme genes including nuclear factor erythroid 2-related factor 2 (Nrf2), heme oxygenase 1 (HO-1), SOD, and glutathione peroxidase (GPx) were improved by FR supplemented into the broiler diets. Based on these results, FR could be acted as a beneficial feed additive with antioxidant capacity and meat quality-improving effect in broiler diets.
\end{abstract}

Article Information
Received 08 October 2018
Revised 11 December 2018
Accepted 20 December 2018
Available online 17 April 2020
Authors' Contribution
XZ and FC conceived and designed
the study. ZS bred the broiler chicks
and collected the samples. JC and GW
analyzed the samples. ZZ analyzed the
data and wrote the article. LZ assisted
in manuscript preparation.
Key words
Fermentation, Radix astragali-ginkgo
leaves, Antioxidant system, Growth,
Meat quality.

\section{INTRODUCTION}

$\mathrm{W}$ ith the development of meat industry, considerable attention has been paid to the improvement of meat quality parameters. Meat producers consistently produce safe, healthy and tasty meat for consumers, accompanied by eliminating deteriorative phenomenon that negatively affects meat quality (Xia et al., 2017). As a major cause of meat deterioration (Asghar et al., 1988), lipid oxidation can produce toxic compounds, such as fatty acid peroxides, cholesterol hydroperoxide and reactive oxygen species (ROS) that adversely influence muscle oxidative stability

\footnotetext{
* Corresponding author: fuliangcaonjfu@163.com 0030-9923/2020/0004-1571 \$9.00/0

Copyright 2020 Zoological Society of Pakistan
}

(Grün et al., 2006). What is more, muscle oxidative stability is related to many aspects of meat quality that are represented by postmortem $\mathrm{pH}$, flavour, color, water holding capacity (WHC), and nutritive value (Luciano et al., 2009; Karami et al., 2011). It decreases the shelf life of meat which leads to economic losses in the meat industry.

In order to improve meat quality and to maximize the oxidative stability of meat, antioxidants are added to feeds. Although synthetic antioxidants, for example, butylated hydroxytoluene and butyl hydroxy anisol have been widely used in the meat industry. The consumer concern over their safety and toxicity have initiated search for natural sources of antioxidants (Nuala et al., 2006). It has been found that plant polyphenolic flavonoids were one of the major groups of compounds acting as primary antioxidant freeradical terminators (Singh et al., 2005). Havsteen (2002) 
reported that, flavonoids in the cell membrane protect the unsaturated fatty acids against oxidants as ascorbate. These flavonoids work as a part of cellular antioxidant systems and in close cooperation with other cellular antioxidants, particularly the ascorbate and glutathione (GSH) systems.

Ginkgo biloba L. (Family: Ginkgoaceae) is a famous traditional herb drug in China, which has been used in many parts of the world showing high physiological activities in therapies for diseases (Pietri et al., 1997; Goh et al., 2003; Naik et al., 2006; Naik and Panda, 2007; Chen et al., 2011). China has had a large-scale production of Ginkgo leaves for years, about 40,000 t every year. In the last few years, large-scale cultivation of Ginkgo has been initiated (Zhang et al., 2012). Therefore, it is important to find a way to use this herbal resource as a feed ingredient and unveil its medicinal potential in the poultry feed industry. Chemically, the active constituents of Ginkgo biloba leaf are flavonoids (flavone glycosides, primarily composed of quercetin, kaempferol and isorhamnetin glycosides) and terpenoids fraction (ginkolides A, B, C, J and bilobalides) (Kleijnen and Knipschild, 1992; Abdel-Kader et al., 2007). The combination of flavonoids (such as quercetin), terpenoids (ginkgolides and bilobalide), and the organic acids contribute to the anti-oxidative properties and free radical scavenging activities of Ginkgo biloba (Le Bars et al., 1997). Up to the present, the assumption that the beneficial effects of Ginkgo biloba leaves are due to its free radical scavenging action has been shown in several studies in vitro (Maitra, et al., 1995; Smith and Luo, 2004) and in vivo (Smith and Luo, 2003; Sarikçioğlu et al., 2004; Shi et al., 2009). Moreover, extract of Ginkgo biloba leaf has been found to be more effective than water-soluble antioxidants (ascorbic acid, glutathione and uric acid), and as effective as lipid-soluble antioxidants (alpha-tocopherol and retinol acetate) in reducing $\mathrm{H}_{2} \mathrm{O}_{2}$-induced oxidative stress in human erythrocytes (Köse and Doğan, 1995). However, there are also considerations with regard to the seasonal variations and storage conditions of the leaves (Ellnain-Wojtaszek et al., 2002).

Radix astragali (RA) is the dried root of Astragalus membranaceus Bge. Var. mongholicus (Huangqi), which is the most popular health-promoting herb in China (Yan et al., 2010). The main constituents of RA roots are polysaccharides, saponins, flavonoids, amino acids, and trace elements (Ma et al., 2002). Therefore, it is important to find out a way to utilize resource of Radix astragaliginkgo leaves as feed ingredient and unveil its potential economic value in feed industry. Toward promoting processing of ginkgo leaves, in this study, a process for Aspergillus niger fermentation was developed wherein the functionality of Radix astragali-ginkgo leaves is preserved and enhanced, with the aim of investigating the effect of
FR on the growth performance, antioxidant capacity, meat quality and plasma biochemical parameters of broiler chicks, and its comparison with the non-fermented (NF) products.

\section{MATERIALS AND METHODS}

\section{Culturing of Aspergillus niger}

The Aspergillus niger used in this study was a laboratory strain obtained from the College of Chemical Engineering, Nanjing Forest University, Nanjing, Jiangsu, China. It was cultured by an agar plating technique using Sabouraud dextrose agar (Oxoid Ltd., Basingstoke, UK) and incubated at $24^{\circ} \mathrm{C}$ for $7 \mathrm{~d}$. Aspergillus niger spores were harvested by tapping the top of the plate when turned upside down. Spore counts were determined using a hematocytometer according to the Fuchs-Rosenthal technique to be approximately $4.0 \times 10^{6}$ spores, which were equivalent to $0.25 \mathrm{~g}$.

\section{Preparation of fermented ginkgo leaves sample}

Comminuted (2.0 -mm sieve) dried ginkgo leaves picked in September (ginkgo garden for leaf use, Nanjing Forestry University, Jiangsu Province, P.R. China) and Radix astragali (purchased from Bozhou Company of Traditional Chinese Medicine, Anhui Province) were used for this study. Samples were divided into 2 lots after autoclave sterilization. One lot was untreated (no fermentation), and the other lot was fermented using Aspergillus niger. Radix astragali-ginkgo leaves were mixed in the mass based ratio of 1:4 (1 part Radix astragali to 4 parts ginkgo leaves). The fermentation medium contained $10 \mathrm{~g}$ solid medium (Radix astragaliginkgo leaves : wheat bran : corncob $=8: 1.5: 0.5$, mass : mass) and $16 \mathrm{~mL}$ nutritive salt (glucose : urea: $\left(\mathrm{NH}_{4}\right)_{2} \mathrm{SO}_{4}$ : peptone : $\mathrm{KH}_{2} \mathrm{PO}_{4}: \mathrm{MgSO}_{4} \cdot 7 \mathrm{H}_{2} \mathrm{O}=4: 2: 6: 1: 4: 1$, mass : mass) and was inoculated with $1 \mathrm{~g} / \mathrm{kg}$ of the spores of Aspergillus niger. The mixture was packed in a plastic container, gently firmed, and sealed with adhesive film before being kept in a room at ambient temperature $\left(24^{\circ} \mathrm{C}\right)$. The sample was fermented for $48 \mathrm{~h}$. Although Aspergillus niger is an aerobic organism, there would be a production phase under micro-aerobic conditions that existed in the closed container (David et al., 2003). The fermented sample was spread on a polythene sheet in a room at 30 to $40^{\circ} \mathrm{C}$, dried for $6 \mathrm{~d}$ up to about $90 \%$ of the dry matter, and ground to pass through a $0.15-\mathrm{mm}$ sieve. The changes of the ingredients before and after the fermentation are shown in Table I. Repetitious examination showed that the proportion of components in polysavone was constant within a minute range. 
Table I.- Nutrient and amino acids composition of Radix astragalis-ginkgo leaves before and after fermentation ${ }^{1}$.

\begin{tabular}{|c|c|c|c|c|c|}
\hline $\begin{array}{l}\text { Radix astragali-ginkgo } \\
\text { leaves }\end{array}$ & $\begin{array}{c}\text { Total flavonoids/mg of } \\
\text { quercetin equivalents/g }\end{array}$ & $\begin{array}{c}\text { Polysaccharides } \\
(\%)\end{array}$ & $\begin{array}{l}\text { Protein } \\
(\%)\end{array}$ & $\begin{array}{c}\text { Total amino acid } \\
(\%)\end{array}$ & $\begin{array}{c}\text { Total ginkgolic acid } \\
(\mathrm{g} / \mathrm{kg})\end{array}$ \\
\hline Before & 9.3 & 0.97 & 10.63 & 8.60 & 1.465 \\
\hline After & 8.8 & 2.05 & 18.29 & 15.88 & 0.033 \\
\hline Increment & -0.5 & 1.08 & 7.66 & 7.28 & -1.432 \\
\hline \multicolumn{6}{|c|}{ Concentration of amino acid (\%) } \\
\hline Indispensable & Before & After & Dispensable & Before & After \\
\hline Lysine & 0.422 & 0.515 & Aspartate & 0.882 & 1.134 \\
\hline Threonine & 0.327 & 0.419 & Serine & 0.396 & 0.476 \\
\hline Leucine & 0.499 & 0.652 & Glutamic acid & 1.260 & 1.505 \\
\hline Isoleucine & 0.296 & 0.386 & Alanine & 0.436 & 0.564 \\
\hline Methionine & 0.061 & 0.049 & Cystine & 0.034 & 0.036 \\
\hline Tryptophan & 0.019 & 0.085 & Valine & 0.428 & 0.547 \\
\hline Phenylalanine & 0.387 & 0.483 & Proline & 0.592 & 0.565 \\
\hline Tyrosine & 0.202 & 0.265 & Total & 4.028 & 4.827 \\
\hline Histidine & 0.366 & 0.353 & & Increment & $799 \%$ \\
\hline Glycine & 0.585 & 0.665 & & & \\
\hline Arginine & 0.407 & 0.489 & & & \\
\hline Total & 3.571 & 4.361 & & & \\
\hline Increment & \multicolumn{2}{|l|}{$0.790 \%$} & & & \\
\hline
\end{tabular}

${ }^{1}$ Mean values. All samples were made in triplicate. The variation coefficient $<2 \%$ batch to batch.

\section{Experimental animal and feeding}

A total of 300 healthy, day-old commercialArbor Acres (AA) broiler chicks, obtained from a local commercial hatchery (Haian, Jiangsu, China), were randomly allocated to 5 treatment groups consisting of 6 replicates of 10 birds each (male and female were equal). The average initial body weight was $52 \mathrm{~g} \pm 3.8 \mathrm{~g}$. The birds were fed a basal diet consisting of maize-soybean meal in which the respective experimental treatments, $3 \mathrm{~g} / \mathrm{kg}$ NF products, 1 $\mathrm{g} / \mathrm{kg}, 3 \mathrm{~g} / \mathrm{kg}$ and $6 \mathrm{~g} / \mathrm{kg}$ products, were included (control, NF, FR1, FR2 and FR3, respectively). All the diets (mash form) of the five treatments were formulated for starter (1 to $21 \mathrm{~d}$ ) and grower (22 to $42 \mathrm{~d}$ ) broiler growth periods (Table II) according to Nutrient Requirements of Poultry (NRC, 1994). Birds in the experimental group received a diet supplemented with different NF or FR levels at the priority expense of wheat bran and posteriorly of maize, based on the control diet; other factors were the same as those in the control group as shown in Table II. Dietary total flavonoids and polysaccharides contents are shown in Table III.

All birds were placed in wire cages in a 3-level battery, each replicate was assigned to a cage $(150 \mathrm{~cm} \times 100 \mathrm{~cm} \times 60$ $\mathrm{cm})$ of 10 chickens $\left(0.15 \mathrm{~m}^{2}\right.$ per chick $)$ and housed in an environmentally controlled room maintained at $34^{\circ} \mathrm{C}$ to $35^{\circ} \mathrm{C}$ for $5 \mathrm{~d}$, and then gradually decreased to $24^{\circ} \mathrm{C}$, after which it was maintained at room temperature and then kept constant. The light regimen was a $12 \mathrm{~h}$ light-dark cycle (06:00 to 18:00 h light) throughout the trial. Both feed and water were provided for ad libitum consumption. Fresh diets were prepared once a week and were stored in sealed bags at $4^{\circ} \mathrm{C}$. The rearing period was 6 weeks.

Broiler growth performance responses such as body weight (BW), body weight gain (BWG), feed intake (FI) and feed intake/gain ratio $(\mathrm{F} / \mathrm{G})$ were determined on a weekly basis during the 6 experimental weeks. Mortality was recorded on a daily basis. Weekly FI per broiler was calculated on a pen basis by dividing the amount of weekly feed consumption (corrected for the feed consumed by the birds that died during the week) by the number of birds alive at the end of the week. For practical reasons performance data were presented on a growth period (i.e. starter and grower period) basis. In addition, overall BWG, FI and $F / G$ were calculated and presented for the entire duration of the experiment.

The experimental design and procedures were approved by the Animal Care and Use Committee of Nanjing Forestry University following the requirements of the Regulations for the Administration of Affairs Concerning Experimental Animals of China. 
Table II.- Ingredients and nutrient composition of broiler diets on as-fed basis.

\begin{tabular}{|c|c|c|c|c|c|c|c|c|c|c|}
\hline \multirow[t]{2}{*}{ Ingredients (\%) } & \multicolumn{5}{|c|}{ Dietary treatments (1 to $21 \mathrm{~d})^{3}$} & \multicolumn{5}{|c|}{ Dietary treatments $(22 \text { to } 42 \mathrm{~d})^{3}$} \\
\hline & Cont. & NF & FR1 & FR2 & FR3 & Cont. & NF & FR1 & FR2 & FR3 \\
\hline Maize & 60.34 & 60.34 & 60.34 & 60.34 & 60.24 & 64.68 & 64.68 & 64.68 & 64.68 & 64.48 \\
\hline Soybean meal (43\%) & 30.22 & 30.22 & 30.22 & 30.22 & 30.22 & 24.23 & 24.23 & 24.23 & 24.23 & 24.23 \\
\hline Maize gluten meal (60\%) & 2.9 & 2.9 & 2.9 & 2.9 & 2.9 & 3.8 & 3.8 & 3.8 & 3.8 & 3.8 \\
\hline Wheat bran & 0.5 & 0.2 & 0.4 & 0.2 & 0 & 0.4 & 0.1 & 0.3 & 0.1 & 0 \\
\hline Non-fermented Radix astragali-ginkgo leaves & 0 & 0.3 & 0 & 0 & 0 & 0 & 0.3 & 0 & 0 & 0 \\
\hline Fermented Radix astragali-ginkgo leaves & 0 & 0 & 0.1 & 0.3 & 0.6 & 0 & 0 & 0.1 & 0.3 & 0.6 \\
\hline Lard & 2.03 & 2.03 & 2.03 & 2.03 & 2.03 & 2.83 & 2.83 & 2.83 & 2.83 & 2.83 \\
\hline Limestone & 1.1 & 1.1 & 1.1 & 1.1 & 1.1 & 1.27 & 1.27 & 1.27 & 1.27 & 1.27 \\
\hline Dicalcium phosphate & 1.49 & 1.49 & 1.49 & 1.49 & 1.49 & 1.27 & 1.27 & 1.27 & 1.27 & 1.27 \\
\hline Sodium chloride & 0.2 & 0.2 & 0.2 & 0.2 & 0.2 & 0.25 & 0.25 & 0.25 & 0.25 & 0.25 \\
\hline L-Lysine & 0.07 & 0.07 & 0.07 & 0.07 & 0.07 & 0.16 & 0.16 & 0.16 & 0.16 & 0.16 \\
\hline DL-Methionine & 0.15 & 0.15 & 0.15 & 0.15 & 0.15 & 0.11 & 0.11 & 0.11 & 0.11 & 0.11 \\
\hline Premix $^{1}$ & 1.0 & 1.0 & 1.0 & 1.0 & 1.0 & 1.0 & 1.0 & 1.0 & 1.0 & 1.0 \\
\hline Total & 100 & 100 & 100 & 100 & 100 & 100 & 100 & 100 & 100 & 100 \\
\hline \multicolumn{11}{|l|}{ Chemical composition $^{2}$} \\
\hline Metabolizable energy (MJ/kg) & 12.3 & 12.3 & 12.3 & 12.3 & 12.3 & 12.6 & 12.6 & 12.6 & 12.6 & 12.6 \\
\hline Crude protein $(\%)$ & 20.07 & 20.07 & 20.07 & 20.07 & 20.04 & 20.3 & 20.3 & 20.3 & 20.3 & 20.3 \\
\hline Calcium (\%) & 1.0 & 1.0 & 1.0 & 1.0 & 1.0 & 0.9 & 0.9 & 0.9 & 0.9 & 0.9 \\
\hline Available phosphorus (\%) & 0.45 & 0.45 & 0.45 & 0.45 & 0.45 & 0.4 & 0.4 & 0.4 & 0.4 & 0.4 \\
\hline Lysine (\%) & 1.13 & 1.13 & 1.13 & 1.13 & 1.13 & 1.0 & 1.0 & 1.0 & 1.0 & 1.0 \\
\hline Methionine (\%) & 0.5 & 0.5 & 0.5 & 0.5 & 0.5 & 0.44 & 0.44 & 0.44 & 0.44 & 0.44 \\
\hline Methionine + cystine $(\%)$ & 0.82 & 0.82 & 0.82 & 0.82 & 0.82 & 0.74 & 0.74 & 0.74 & 0.74 & 0.74 \\
\hline Threonine & 0.77 & 0.77 & 0.77 & 0.77 & 0.77 & 0.71 & 0.71 & 0.71 & 0.71 & 0.71 \\
\hline
\end{tabular}

${ }^{1}$ Premix provided per kilogram of diet: transretinyl acetate, $30 \mathrm{mg}$; $\alpha$-tocopherol acetate, $30 \mathrm{mg}$; cholecalciferol, $6 \mathrm{mg}$; menadione, $1.3 \mathrm{mg}$; thiamin, 2.2 $\mathrm{mg}$; riboflavin, $8 \mathrm{mg}$; nicotinamide, $40 \mathrm{mg}$; choline chloride, $400 \mathrm{mg}$; calcium pantothenate, $10 \mathrm{mg}$; pyidoxine $\cdot \mathrm{HCl}, 4 \mathrm{mg}$; biotin, $0.04 \mathrm{mg}$; folic acid, 1 $\mathrm{mg}$; vitamin $\mathrm{B}_{12}$ (cobalamin), $0.013 \mathrm{mg}$; Fe (from ferrous sulfate), $80 \mathrm{mg}$; $\mathrm{Cu}$ (from copper sulfate), $7.5 \mathrm{mg}$; Mn (from manganese sulfate), $110 \mathrm{mg}$; $\mathrm{Zn}$ (from zinc oxide), $65 \mathrm{mg}$; (from calcium iodate), $1.1 \mathrm{mg}$; Se (from sodium selenite), $0.3 \mathrm{mg}$; Bacitracin Zinc, $30 \mathrm{mg}$.

${ }^{2}$ Calculated based on analyzed values of individual feed ingredient except for energy which was based on published ME values.

${ }^{3}$ Cont. = Basal diet; NF = Basal diet with $3 \mathrm{~g} / \mathrm{kg}$ non-fermented Radix astragali-ginkgo leaves; FR1, FR2 and FR3 = Basal diet with 1 g/kg, 3 g/kg and 6 $\mathrm{g} / \mathrm{kg}$, respectively, fermented Radix astragali-ginkgo leaves.

Table III.- Total flavonoids and polysaccharides contents in the diets ${ }^{1}$ of broilers.

\begin{tabular}{|c|c|c|c|c|}
\hline \multirow[t]{2}{*}{ Dietary treatments } & \multicolumn{2}{|c|}{$\begin{array}{c}\text { Total flavonoids/mg of quercetin } \\
\text { equivalent/kg }\end{array}$} & \multicolumn{2}{|c|}{$\begin{array}{c}\text { Total polysaccharides/ } \\
\mathrm{mg} / \mathrm{kg}\end{array}$} \\
\hline & 1 to $21 \mathrm{~d}$ & 22 to $42 \mathrm{~d}$ & 1 to $21 \mathrm{~d}$ & 22 to $42 \mathrm{~d}$ \\
\hline Basal diet & $2.85^{\mathrm{d}}$ & $3.34^{\mathrm{d}}$ & $1.51^{\mathrm{d}}$ & $1.48^{\mathrm{d}}$ \\
\hline Non-fermented Radix astragali-ginkgo leaves (3 g/kg) & $19.82^{\mathrm{b}}$ & $19.75^{\mathrm{b}}$ & $20.34^{\mathrm{c}}$ & $19.80^{\mathrm{c}}$ \\
\hline Fermented Radix astragali-ginkgo leaves (1 g/kg) & $9.11^{\mathrm{c}}$ & $8.75^{\mathrm{c}}$ & $21.75^{\mathrm{c}}$ & $20.34^{\mathrm{c}}$ \\
\hline Fermented Radix astragali-ginkgo leaves ( $3 \mathrm{~g} / \mathrm{kg})$ & $17.46^{\mathrm{b}}$ & $17.03^{\mathrm{b}}$ & $44.14^{\mathrm{b}}$ & $43.87^{\mathrm{b}}$ \\
\hline Fermented Radix astragali-ginkgo leaves $(6 \mathrm{~g} / \mathrm{kg})$ & $29.65^{\mathrm{a}}$ & $28.63^{\mathrm{a}}$ & $63.71^{\mathrm{a}}$ & $61.97^{\mathrm{a}}$ \\
\hline Standard error of mean & 1.91 & 1.83 & 4.40 & 4.32 \\
\hline \multicolumn{5}{|l|}{$P$-values } \\
\hline ANOVA & 0.001 & 0.001 & 0.001 & 0.001 \\
\hline \multicolumn{5}{|l|}{ Regression } \\
\hline Linear & 0.001 & 0.001 & 0.001 & 0.001 \\
\hline Quadratic & 0.001 & 0.001 & 0.001 & 0.001 \\
\hline
\end{tabular}

\footnotetext{
a, b, c Means having a common superscript in a sub-column do not vary significantly $(P>0.05)$.

${ }^{1}$ Six different samples from each diet were randomly selected and determined.
} 


\section{Sampling procedures}

At 21 and 42 days of age, one bird was randomly selected from each replicate ( 6 birds per treatment, 3 males and 3 females) and weighed after feed deprivation for 12 h. Individual blood samples were taken via brachial vein and serum were separated by centrifugation at $350 \mathrm{~g}$ for $15 \mathrm{~min}$ and at $4^{\circ} \mathrm{C}$. Serum samples were frozen at $-20^{\circ} \mathrm{C}$ for further analyzing. At 42 day, after collection of blood samples, all birds were euthanized by exsanguination immediately. After that, samples of liver and muscle were rapidly excised, frozen in liquid nitrogen and stored at $-80^{\circ} \mathrm{C}$ until body composition analysis. The carcasses were then necropsied and the abdominal fat pad were removed and weighed. Relative weight of abdominal fat was calculated as [weight $(\mathrm{g}) / \mathrm{BW}(100 \mathrm{~g})]$.

\section{Serum analysis}

Plasma $\alpha$-tocopherol $(\alpha-\mathrm{TOH})$ was analyzed as described by Kayden et al. (1973). The samples were saponified by mixing $1 \mathrm{~mL}$ serum with a $2 \%$ pyrogallol solution $(5 \mathrm{~mL})$ and heated for $2 \mathrm{~min}$ in a $70^{\circ} \mathrm{C}$ shaking water bath. The tubes were removed, and $0.25 \mathrm{~mL}$ of $11 \mathrm{~N} \mathrm{KOH}$ was added. The tubes were heated again in (shaking) $70^{\circ} \mathrm{C}$ water bath for $30 \mathrm{~min}$, and then placed in an ice bath. Two milliliters of hexane (used to extract the VE) and $0.5 \mathrm{~mL}$ of water were added to the saponified samples and shaken vigorously for $2 \mathrm{~min}$. One milliliter of the hexane layer was transferred to a $4 \mathrm{~mL}$ glass test tube for analysis. Standards of 1, 2, 4, 6, 8, and $10 \mu \mathrm{g}$ / $\mathrm{mL}$ of $\alpha-\mathrm{TOH}$ were prepared at the same time. A $0.2 \%$ bathophenanthroline solution $(200 \mu \mathrm{L})$ was added to all the samples and standards and thoroughly mixed. Two hundred microliters of $1 \mathrm{mM} \mathrm{FeCl}_{3}$ was added and samples were vortexed. After $1 \mathrm{~min}, 200 \mu \mathrm{L}$ of an $\mathrm{H}_{3} \mathrm{PO}_{4}$ solution was added and vortexed again. The tubes were read on a spectrophotometer at $534 \mathrm{~nm}$. The standard curve was used to calculate the concentration of $\alpha-\mathrm{TOH}$ in each sample. The concentrations of $\alpha$-TOH were expressed as $\mu \mathrm{g} / \mathrm{mL}$.

Determination of serum total cholesterol (TC), glutathione (GSH), malondialdehyde (MDA) concentrations, total superoxide dismutase (T-SOD) activities, and sarcous lactic acid (LD) were done using the corresponding diagnostic kits (Nanjing Jiancheng Bioengineering Institute, Nanjing, P.R. China) according to the instructions of the manufacturer.

\section{Hepatic mitochondria isolation and ROS determination}

Hepatic mitochondria were prepared according to the method described by Bai et al. (2017). Namely, liver tissue was homogenized in ice-chilled Dounce homogenizers $(1: 10, \mathrm{w} / \mathrm{v})$ using isolation buffer containing $10 \mathrm{mM}$ MOPS pH 7.4, $250 \mathrm{mM}$ sucrose, $5 \mathrm{mM} \mathrm{KH}_{2} \mathrm{PO}_{4}, 2 \mathrm{mM}$
$\mathrm{MgCl}_{2}, 1 \mathrm{mM}$ EGTA, and $0.1 \%$ fatty acid-free BSA, and centrifuged at $1,000 \times \mathrm{g}$ for $5 \mathrm{~min}$ at $4^{\circ} \mathrm{C}$. The supernatants were removed and the mitochondria-enriched pellets gently resuspended and washed with the isolation buffer, then the pellets obtained by centrifugation at $12,000 \times g$ for $5 \mathrm{~min}$. Mitochondria were lysed and the protein was measured using the Micro BCA protein assay kit (Nanjing Jiancheng Bioengineering Institute) according to the manufacturers' instructions.

The ROS concentrations in the liver mitochondria of broiler chickens were detected using a ROS assay kit (Nanjing Jiancheng Bioengineering Institute) according to the manufacturers' instructions. Briefly, the mitochondria were incubated with DCFH-DA $(10 \mu \mathrm{M})$ and DNA stain Hoechst $33342(10 \mathrm{mmol} / \mathrm{L})$ at $37^{\circ} \mathrm{C}$ for $30 \mathrm{~min}$. Then the DCFH fluorescence of the mitochondria was measured at an emission wavelength of $530 \mathrm{~nm}$ and an excitation wavelength of $485 \mathrm{~nm}$ with a microplate fluorescence reader (BioTek Instruments Inc., Synergy ${ }^{\mathrm{TM}} 2$ ). The results were expressed as the mean DCFH-DA fluorescence intensity over that of the control.

\section{Quantitative real-time PCR analyses}

Total RNA was obtained from the liver using Trizol Reagent (TaKaRa, Dalian, China) and then reversetranscribed using a commercial kit (Perfect Real Time, SYBR $^{\circledR}$ PrimeScript ${ }^{\mathrm{TM}}$, TaKaRa) following the instructions of the manufacturer. The mRNA expression levels of specific genes were quantified via real-time PCR, using SYBR $^{\circledR}$ Premix Ex Taq $^{\mathrm{TM}}$ II (Tli RNaseH Plus) and an ABI StepOnePlus ${ }^{\mathrm{TM}} 167$ Real-Time PCR system (Applied Biosystems, Grand island, NY, USA).

Table IV.- Primer sequences used for Real-time PCR assay.

\begin{tabular}{|c|c|c|}
\hline Name $^{1}$ & Sequence $\left(5^{\prime} \rightarrow 3^{\prime}\right)^{2}$ & $\begin{array}{c}\text { Genbank } \\
\text { Accession No. }\end{array}$ \\
\hline \multirow[t]{2}{*}{$\beta$-Actin } & TGCTGTGTTCCCATCTATCG & NM_205518.1 \\
\hline & TTGGTGACAATACCGTGTTCA & \\
\hline \multirow[t]{2}{*}{$N r f 2$} & GATGTCACCCTGCCCTTAG & NM_205117.1 \\
\hline & CTGCCACCATGTTATTCC & \\
\hline \multirow[t]{2}{*}{$H O-1$} & GGTCCCGAATGAATGCCCTTG & HM237181.1 \\
\hline & ACCGTTCTCCTGGCTCTTGG & \\
\hline \multirow[t]{2}{*}{$S O D$} & CCGGCTTGTCTGATGGAGAT & NM_205064.1 \\
\hline & TGCATCTTTTGGTCCACCGT & \\
\hline \multirow[t]{2}{*}{$G P x$} & GACCAACCCGCAGTACATCA & NM \\
\hline & GAGGTGCGGGCTTTCCTTTA & 001277853.1 \\
\hline
\end{tabular}

${ }^{1}$ Nuclear factor erythroid 2-related factor 2 (Nrf2); Heme oxygenase 1 (HO-1); Superoxide dismutase (SOD); Glutathione peroxidase (GPx). ${ }^{2}$ Shown as forward primer followed by reverse primer. 
The SYBR Green PCR reaction mixture consisted of $10 \mu \mathrm{L}$ SYBR $^{\circledR}$ Premix Ex Taq (2X), $0.4 \mu$ of the forward and reverse primers, $0.4 \mu \mathrm{L}$ of ROX reference dye (50X), $6.8 \mu \mathrm{L}$ of $\mathrm{ddH}_{2} \mathrm{O}$ and $2 \mu \mathrm{L}$ of cDNA template. Each sample was amplified in triplicate. The fold-expression of each gene was calculated according to the $2^{-\Delta \Delta \mathrm{Ct}}$ method (Bai et al., 2017), in which the $\beta$-Actin gene was used as an internal standard. The primer sequences used are given in Table IV.

\section{Carcass and meat quality analysis}

At $42 \mathrm{~d}$, after all birds were killed by manual exsanguinations and manually eviscerated, the carcass and eviscerated carcass yield, abdominal fat (including fat around the gizzard), breast meat (including pectoralis major and pectoralis minor), and leg meat (including thigh and drumstick) were equally measured. Carcass yield and eviscerated carcass percentage was calculated as the ratio between the carcass or eviscerated carcass and live BW after fasting. The weight percentages of breast meat, leg meat, and abdominal fat were calculated as a percentage of eviscerated carcass weight.

Muscle samples were collected from the left side of the pectoralis major muscle for the determination of physico-chemical characteristics (water, protein, fat, water-holding capacity and $\mathrm{pH}$ ) of the breast muscle.

The ultimate $\mathrm{pH}$ values (measurements done in triplicate) of the pectoralis muscles were measured 45 min postmortem, using a calibrated portable $\mathrm{pH}$ meter (HI9023, Hanna Instruments, Padova, Italy) equipped with an insertion glass electrode (FC 230B, Hanna Instruments). The meat samples were always measured at the same place for $\mathrm{pH}$.

Water holding capacity was estimated by determining expressible juice using modification of the filter paper press method described by Wang et al. (2009). A raw meat sample weighing $1,000 \mathrm{mg}$ was placed between 18 pieces of 11-cm-diameter filter paper and pressed at $35 \mathrm{~kg}$ for $5 \mathrm{~min}$. Expressed juice was defined as the loss in weight after pressing and presented as a percentage of the initial weight of the original sample.

Proximate analyses of water, protein (nitrogen), and fat contents of the breast muscle were determined by AOAC (2000) methods. Nitrogen was determined using the Kjeltec Analyzer Unit (2300, Foss, Höganäs, Sweden) and crude lipid was determined by ether extraction using the Soxtec Auto Extraction Unit (2050, Foss, Tecator, Sweden). The amino acid composition of the NF and FR products was determined using an automatic amino acid analyzer L-8500 (Hitachi, Tokyo, Japan) after the samples were hydrolyzed in $6 \mathrm{~N} \mathrm{HCl}$ for $22 \mathrm{~h}$ at $110^{\circ} \mathrm{C}$, as described in Gui et al. (2010). Gross energy content of diets was determined on a Parr 1281 adiabatic calorimeter (Moline, Illinois, USA). Apparent metabolisable energy (AME) content was corrected for nitrogen retention by assuming that weight gain consisted of $200 \mathrm{~g}$ protein $/ \mathrm{kg}$, that protein consisted of $160 \mathrm{~g}$ nitrogen $/ \mathrm{kg}$, and that the energy equivalent was $34.36 \mathrm{~kJ} / \mathrm{g}$ nitrogen gained (Bourdillon et al., 1990).

Total flavonoids, polysaccharides and ginkgolic acids analysis

The contents of total flavonoids, polysaccharides and ginkgolic acids were analyzed according to our previous study (Yu et al., 2015; Zhang et al., 2015). The aluminumchloride colorimetric method described by Chang et al. (2002) and Verzelloni et al. (2007) was used to determine the total contents of flavonoids with some modifications. The concentration of total polysaccharides was determined by colorimetric method of phenol-suluric acid assay (Dubois et al., 1956) taking D-glucose as standard control. The content of total ginkgolic acids in G. biloba leaves was determined by HPLC. A Alltima C18 (4.6 mm $\times 250 \mathrm{~mm}, 5$ microm) and the mobile phase of methanol and $1 \%$ acetic acid $(90: 10)$ were used, the flow rate was $1.0 \mathrm{~mL} \times \min \left({ }^{-1}\right)$, and the wavelength was 310 $\mathrm{nm}$. The content was calculated with external standard method.

\section{Statistical analysis}

The effects of dietary treatment were determined by one-way analysis of variance (ANOVA, SAS 9.0) followed, where appropriate, by Tukey's comparison test. Percentage data and data which were identified as nonhomogeneous (Bartlett's test) were subjected to arcsine transformation before analysis. The effect of supplementing graded concentrations of FR on various dependent parameters was analysed by regression analysis. Differences among treatments were separated using polynomial orthogonal contrasts to determine linear and quadratic responses. Values in the tables were means and pooled SEM. Statistical significance was determined at $P \leq 0.05$.

\section{RESULTS}

\section{Growth performance}

Table V showed that no differences $(P>0.05)$ occurred in BWG, FI and F/G among the treatments in the period of 1 to $21 \mathrm{~d}, 22$ to $42 \mathrm{~d}$ and the overall period of 1 to $42 \mathrm{~d}$. No differences were observed on the mortality during the whole period of 1 to $42 \mathrm{~d}(P>0.05)$. 
Table V.- Growth performance of broilers fed maize-basal diets supplemented with NF or FR products.

\begin{tabular}{|c|c|c|c|c|c|c|c|c|c|c|}
\hline \multirow[t]{3}{*}{ Items } & \multicolumn{5}{|c|}{ Dietary treatments ${ }^{1}$} & \multirow[t]{3}{*}{ SEM $^{3}$} & \multirow[t]{3}{*}{$n^{4}$} & \multicolumn{3}{|c|}{ P-values } \\
\hline & \multirow[t]{2}{*}{ Cont. } & \multirow[t]{2}{*}{ NF } & \multirow[t]{2}{*}{ FR1 } & \multirow[t]{2}{*}{ FR2 } & \multirow[t]{2}{*}{ FR3 } & & & \multirow[t]{2}{*}{ ANOVA } & \multicolumn{2}{|c|}{ Regression } \\
\hline & & & & & & & & & Linear & Quadratic \\
\hline \multicolumn{11}{|l|}{1 to $21 \mathrm{~d}$} \\
\hline $\mathrm{BWG}^{2}, \mathrm{~kg}$ & 0.618 & 0.617 & 0.638 & 0.644 & 0.647 & 0.005 & 6 & 0.168 & 0.190 & 0.471 \\
\hline $\mathrm{FI}^{2}, \mathrm{~g} / \mathrm{bird} / \mathrm{d}$ & 46.74 & 45.39 & 46.05 & 47.42 & 46.80 & 0.443 & 6 & 0.332 & 0.568 & 0.758 \\
\hline $\mathrm{F} / \mathrm{G}^{2}$ & 1.588 & 1.545 & 1.516 & 1.546 & 1.519 & 0.093 & 6 & 0.099 & 0.494 & 0.738 \\
\hline \multicolumn{11}{|l|}{22 to $42 \mathrm{~d}$} \\
\hline $\mathrm{BWG}^{2}, \mathrm{~kg}$ & 1.470 & 1.456 & 1.517 & 1.521 & 1.531 & 0.015 & 6 & 0.422 & 0.094 & 0.188 \\
\hline $\mathrm{FI}^{2}, \mathrm{~g} / \mathrm{bird} / \mathrm{d}$ & 135.88 & 133.21 & 136.61 & 138.52 & 137.97 & 0.904 & 6 & 0.234 & 0.469 & 0.750 \\
\hline $\mathrm{F} / \mathrm{G}^{2}$ & 1.941 & 1.921 & 1.891 & 1.913 & 1.892 & 0.013 & 6 & 0.715 & 0.255 & 0.448 \\
\hline \multicolumn{11}{|l|}{1 to $42 \mathrm{~d}$} \\
\hline $\mathrm{BWG}^{2}, \mathrm{~kg}$ & 2.088 & 2.073 & 2.155 & 2.165 & 2.178 & 0.016 & 6 & 0.258 & 0.054 & 0.114 \\
\hline $\mathrm{FI}^{2}, \mathrm{~g} / \mathrm{bird} / \mathrm{d}$ & 91.31 & 89.30 & 91.33 & 92.97 & 92.39 & 0.654 & 6 & 0.477 & 0.437 & 0.728 \\
\hline $\mathrm{F} / \mathrm{G}^{2}$ & 1.837 & 1.809 & 1.780 & 1.804 & 1.782 & 0.012 & 6 & 0.629 & 0.304 & 0.439 \\
\hline Mortality rate $(\%)$ & 2.69 & 2.56 & 2.42 & 2.05 & 2.03 & 0.08 & 6 & 0.565 & 0.648 & 0.865 \\
\hline
\end{tabular}

${ }^{1}$ Cont. $=$ Basal diet; NF = Basal diet with $3 \mathrm{~g} / \mathrm{kg}$ non-fermented Radix astragali-ginkgo leaves; FR1, FR2 and FR3 = Basal diet with $1 \mathrm{~g} / \mathrm{kg}, 3 \mathrm{~g} / \mathrm{kg}$ and 6 $\mathrm{g} / \mathrm{kg}$, respectively, fermented Radix astragali-ginkgo leaves.

${ }^{2} \mathrm{BWG}=$ body weight gain; $\mathrm{FI}=$ feed intake; $\mathrm{F} / \mathrm{G}=$ feed intake/gain ratio.

${ }^{3}$ Standard error of mean.

${ }^{4} n=$ number of replicates per treatment.

Table VI.- Meat qualities of broilers fed maize-basal diets supplemented with NF or FR products.

\begin{tabular}{|c|c|c|c|c|c|c|c|c|c|c|}
\hline \multirow[t]{3}{*}{ Items } & \multicolumn{5}{|c|}{ Dietary treatments $^{1}$} & \multirow[t]{3}{*}{ SEM $^{4}$} & \multirow[t]{3}{*}{$n^{5}$} & \multicolumn{3}{|c|}{ P-values } \\
\hline & \multirow[t]{2}{*}{ Cont. } & \multirow[t]{2}{*}{ NF } & \multirow[t]{2}{*}{ FR1 } & \multirow[t]{2}{*}{ FR2 } & \multirow[t]{2}{*}{ FR3 } & & & \multirow[t]{2}{*}{ ANOVA } & \multicolumn{2}{|c|}{ Regression } \\
\hline & & & & & & & & & Linear & Quadratic \\
\hline Water $(\mathrm{g} / \mathrm{kg})$ & 754.7 & 758.9 & 753.3 & 758.9 & 761.4 & 0.03 & 6 & 0.104 & 0.124 & 0.369 \\
\hline Protein (g/kg) & 228.3 & 223.8 & 227.3 & 233.8 & 231.5 & 1.88 & 6 & 0.554 & 0.389 & 0.696 \\
\hline Fat $(\mathrm{g} / \mathrm{kg})$ & $14.8^{\mathrm{a}}$ & $13.5^{\mathrm{ab}}$ & $12.2^{\mathrm{b}}$ & $12.5^{\mathrm{b}}$ & $12.7^{\mathrm{b}}$ & 0.30 & 6 & 0.010 & 0.064 & 0.007 \\
\hline $\mathrm{WHC}^{2}$ & $54.69^{\mathrm{b}}$ & $56.93^{\mathrm{a}}$ & $57.21^{\mathrm{a}}$ & $57.34^{\mathrm{a}}$ & $58.21^{\mathrm{a}}$ & 2.93 & 6 & 0.001 & 0.004 & 0.011 \\
\hline $\mathrm{pH}_{45 \min }$ & $5.72^{\mathrm{c}}$ & $5.74^{\mathrm{c}}$ & $5.75^{\mathrm{c}}$ & $5.86^{\mathrm{b}}$ & $5.91^{\mathrm{a}}$ & 0.021 & 6 & 0.001 & 0.003 & 0.001 \\
\hline $\mathrm{LD}^{2}$ (mmol/g of protein) & $3.64^{\mathrm{a}}$ & $3.41^{\mathrm{ab}}$ & $3.19^{\mathrm{b}}$ & $3.17^{\mathrm{b}}$ & $3.12^{\mathrm{b}}$ & 0.016 & 6 & 0.046 & 0.075 & 0.058 \\
\hline Percentage of abdominal fat ${ }^{3}$ & $1.53^{\mathrm{a}}$ & $1.49^{\mathrm{ab}}$ & $1.40^{\mathrm{bc}}$ & $1.43^{\mathrm{bc}}$ & $1.37^{\mathrm{c}}$ & 0.019 & 6 & 0.017 & 0.095 & 0.006 \\
\hline
\end{tabular}

\footnotetext{
Means having a common superscript in a sub-column do not vary significantly $(P>0.05)$.

${ }^{1}$ Cont. = Basal diet; $\mathrm{NF}=$ Basal diet with $3 \mathrm{~g} / \mathrm{kg}$ non-fermented Radix astragali-ginkgo leaves; FR1, FR2 and FR3 = Basal diet with $1 \mathrm{~g} / \mathrm{kg}, 3 \mathrm{~g} / \mathrm{kg}$ and 6 $\mathrm{g} / \mathrm{kg}$, respectively, fermented Radix astragali-ginkgo leaves.

${ }^{2} \mathrm{WHC}=$ water-holding capacity. $\mathrm{LD}=$ Lactic acid.

${ }^{3}$ Calculated as a percentage of eviscerated carcass weight.

${ }^{4}$ Standard error of mean.

${ }^{5} n=$ number of animals per treatment.
}

\section{Meat quality}

As seen in Table VI, there was no $(P>0.05)$ difference between dietary treatments in terms of the contents of water and protein of the muscle. The contents of sarcous fat from chicks fed the diets FR1, FR2 and FR3 was lower $(P<0.05)$ than those from birds fed the control diet. The WHC in group NF, FR1, FR2 and FR3 exerted a 4.10\%, 4.61\%, 4.85\% and $6.44 \%$ increase $(P<0.05)$ respectively, compared with the control group. While group FR2 $(P<0.05)$ and FR3 $(P<0.01)$ exhibited higher $\mathrm{pH}$ compared with the control, $\mathrm{NF}$ and FR1 group. In addition, group FR3 had higher $(P<0.05)$ muscle $\mathrm{pH}$ than that of group FR2. While the contents of sarcous LD were decreased $(\mathrm{P}=0.046)$ by the inclusion of FR. Percentage of the abdominal fat of broilers for group FR1 and FR2 were decreased $(\mathrm{P}<0.05)$ by $8.47 \%$ and $6.51 \%$, respectively, in comparison with the control. 

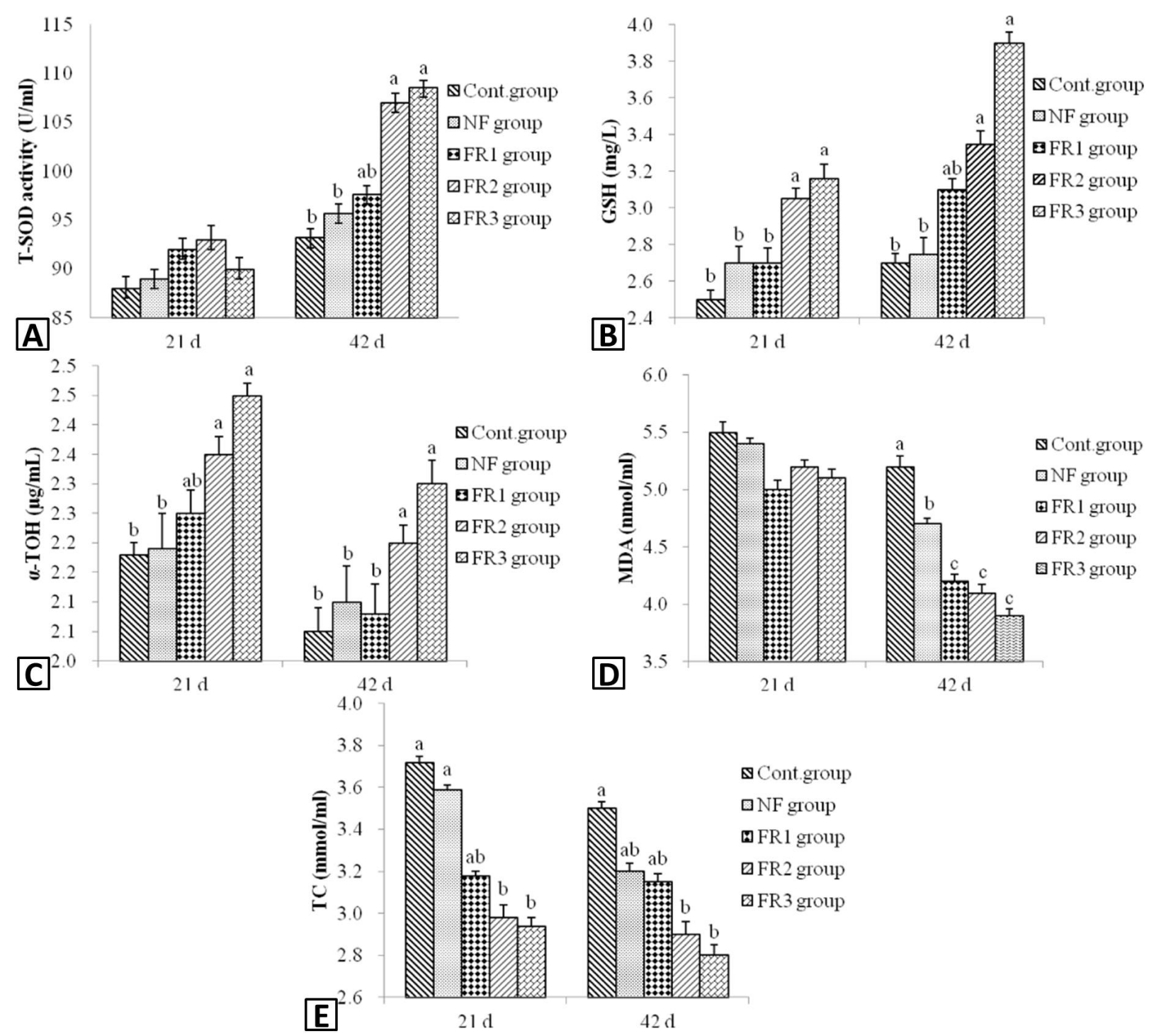

Fig. 1. Serum T-SOD activities (A), GSH (B), MDA (C) $\alpha$-TOH (D) and TC concentrations (E) of broilers fed maize-basal diets supplemented with NF or FR products. ${ }^{\mathrm{a}, \mathrm{b}, \mathrm{c}}$ means with different letters differ significantly $(\mathrm{P}<0.05$ or $\mathrm{P}<0.01)$, compared with the control group within the same time period.

${ }^{1}$ Cont. = Basal diet; $\mathrm{NF}=$ Basal diet with $3 \mathrm{~g} / \mathrm{kg}$ non-fermented Radix astragali-ginko leaves; FR1, FR2 and FR3=Basal diet with $1 \mathrm{~g} / \mathrm{kg}, 3 \mathrm{~g} / \mathrm{kg}$ and $6 \mathrm{~g} / \mathrm{kg}$, respectively, fermented Radix astragali-ginko leaves.

${ }^{2} \mathrm{~T}$-SOD, total superoxide dismutase; GSH, glutathione; MDA, malondialdehyde; TC, total cholesterol; $\alpha$-TOH, $\alpha$-tocopherol.

${ }^{3} \mathrm{n}=6$ (number of animals per treatment).

Also, group FR3 exerted the greatest effect, as it led to a decrease of $10.46 \%$ and $8.05 \%$ as compared to the control $(\mathrm{P}<0.05)$ or NF group $(\mathrm{P}<0.05)$, respectively.

\section{Indicators in serum}

The results of the T-SOD activities, concentrations of GSH, $\alpha-\mathrm{TOH}, \mathrm{MDA}$, and TC in the serum are summarized in Figure 1. The T-SOD activities were significantly increased in FR2 and FR3 groups compared with that in the NF or control group at 42 days of age $(P<0.05)$, and no difference $(P>0.05)$ was observed for the T-SOD activities at 21 days of age, although there was an increasing tendency in the FR groups (Fig. 1A). Concentrations of GSH and $\alpha$-TOH were significantly improved $(P<0.05)$ in groups FR2 and FR3 compared with that in NF and FR1 group, at 21 and 42 day of age (Fig. 1B, C). In addition, a significant increase $(P<0.05)$ of serum GSH $(21 \mathrm{~d})$ and $\alpha$-TOH (42 d) contents were observed in group FR2 and 
FR3 compared with that in FR1 group.

Serum MDA levels did not differ among the treatments $(P<0.05)$, showing a tendency to be decreased in the FR groups at $21 \mathrm{~d}$ (Fig. 1D), while MDA levels for group FR1, FR2 and FR3 at $42 \mathrm{~d}$ were decreased compared with the control $(P<0.01)$ and NF group $(P<0.05)$. A significant reduction $(P<0.05)$ of serum TC concentration was observed in FR2 and FR3 groups (Fig. 1E) compared with that in control ( $21 \mathrm{~d}$ and $42 \mathrm{~d}$ ) and NF group (42 d).

Hepatic mitochondria ROS and mRNA expression levels

Supplemental effects of dietary FR on hepatic mitochondria ROS and mRNA expression levels of antioxidant genes of broilers at $42 \mathrm{~d}$ are shown in Figures 2 and 3. The ROS contents in liver mitochondria (Fig. 2) were significantly decreased $(P<0.05)$ in group FR2 and FR3 compared with that in the control, NF and FR1 groups.

The expression levels of antioxidant gene, including $N r f 2, H O-1$ and GPx in broiler liver were significantly improved $(P<0.05)$ in both FR2 and FR3 groups compared with that in control and NF group. Higher expression level

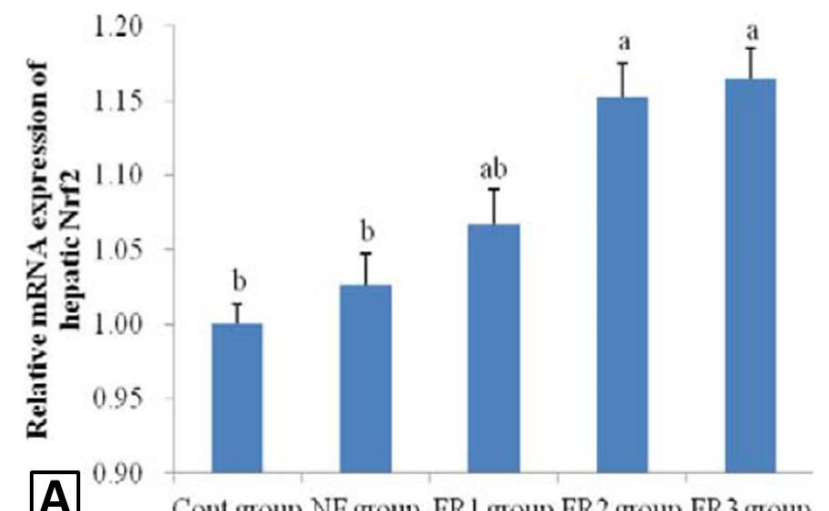

A Cont.goup NF group FR1 group FR2 group FR3 group

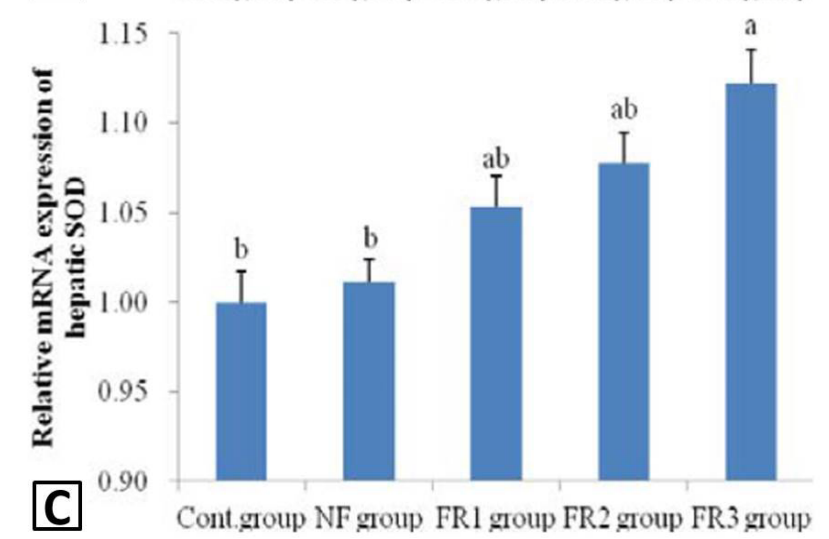

of $\mathrm{HO}-1$ gene was noted in both FR2 and FR3 groups compared with that in group FR1. The expression level of SOD was significantly enhanced $(P<0.05)$ in FR3 group compared with that in control and NF group.

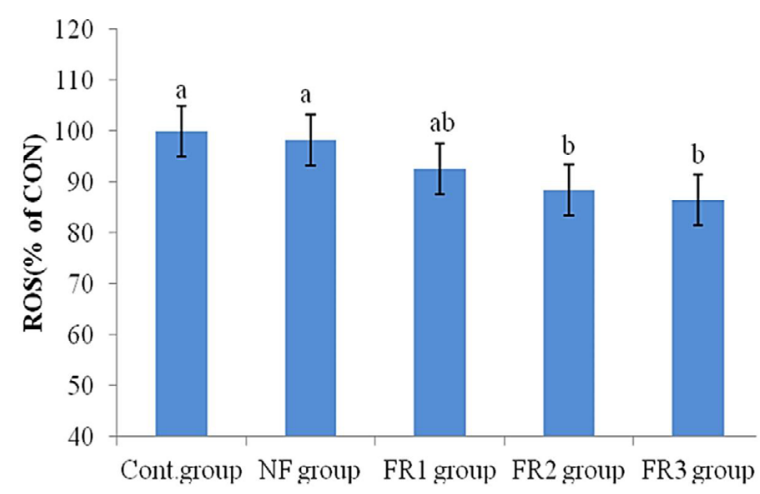

Fig. 2. Contents of hepatic mitochondria ROS of broilers fed maize-basal diets supplemented with NF and FR products.

${ }^{2}$ ROS, reactive oxygen species. For other statistical details, see Figure 1.

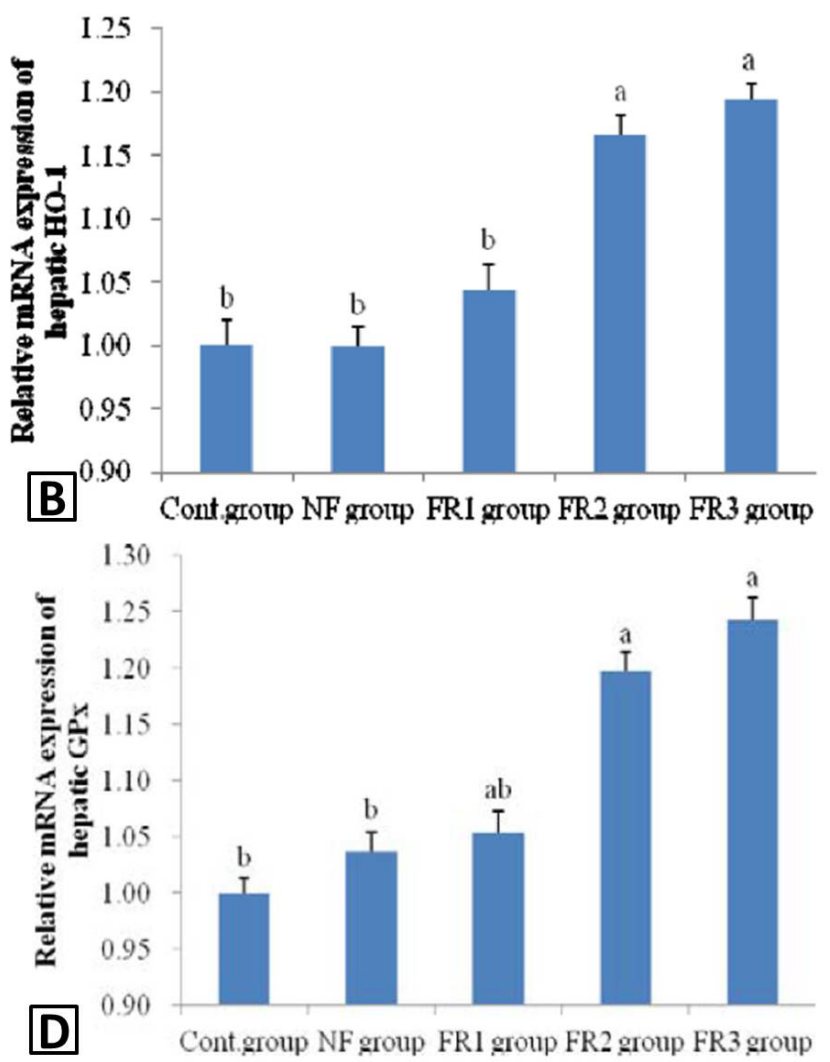

Fig. 3. Expression levels of antioxidant gene in liver of broilers fed maize-basal diets supplemented with NF or FR products. ${ }^{2} \mathrm{Nrf} 2$, nuclear factor erythroid 2-related factor 2; HO-1, Heme oxygenase 1; SOD, superoxide dismutase; GPx, glutathione peroxidase. For other statistical details, see Figure 1. 


\section{DISCUSSION}

Microbial fermentation has been identified as a fruitful process for improving the health-promoting properties of medicinal plants. The fermentation process can alter the original bioactivities and nutritional composition of Chinese herbs (Yamamoto et al., 2007; $\mathrm{Ng}$ et al., 2011; Ahmed et al., 2016), reduce the antinutrient effects (Deacon, 2005), resulting in new treatment effects, and enhance the original treatment efficacy of active ingredients (Miyake et al., 2005; Dei et al., 2008) by the action of enzymes produced by bacteria, yeast and molds. The fermentation process does not require the use of chemicals and is easy to manage under farm conditions or on an industrial scale. Fermentation processes using aspergilli have been used to improve the nutritive value of some feedstuffs (Mathivanan et al., 2006; Yamamoto et al., 2007) for poultry. Our previous researches have confirmed that the use of up to $0.5 \%$ (in the starter phase) and $1.0 \%$ (in the grower phase) Aspergillus niger-fermented-Ginkgo biloba leaves (FR) products had a positive influence on growth performance, lipid metabolism, antioxidant capacity, breast meat quality, and fatty acid composition (Cao et al., 2012; Zhang et al., 2012).

In the present experiment, the increase of polysaccharides may be due in part to the decreased carbohydrate content after fermentation (Hong et al., 2004). In detail, Aspergillus niger is a fungus that has the capacity to produce enzymes such as cellulose, hemicellulases, $\beta$-glucosidase, hydrolases, pectinases, lipases, and tannases (Mathivanan et al., 2006; Dei et al., 2008). These enzymatic components act synergistically in the hydrolysis of $1,4-\beta$ bonds within cellulose molecules, cellobiose and low-molecular-weight cellodextrins, thereby yielding glucose (Leschine, 1995). Total flavonoids contents of FR were found to be decreased slightly after fermentation, suggesting that $\beta$-glucosidase from Aspergillus niger might have converted the flavonoids glycones into aglycones, which has been proved to have greater activity than flavonoid glycones (Hsu and Chiang, 2009). In addition, ginkgolic acids have been recognized as hazardous compounds with suspected cytotoxic, allergenic, mutagenic and carcinogenic properties, and they were found to be decreased sharply after fermentation in the current study (Liu and Zeng, 2009; Yu et al., 2015).

There are several published works on the lipolytic activity of flavonoids in vitro and in mammals (Nakagawa et al., 2004; Hsu and Yen, 2007; Zarrouki et al., 2010). Previous studies suggested (Honda et al., 2009; Aoki et al., 2009) that flavonoid exerts potent antilipogenic effect by decreasing adipose tissue deposition and ameliorating diet-induced obesity in mice. Moreover, it was well documented that some flavonoids form insoluble complexes with cholesterol in the digesta and inhibit the intestinal absorption of endogenous and exogenous cholesterol (Rao and Gurfinkel, 2000). Jang et al. (2007) demonstrated that TC content was decreased by fermented ginseng culture in laying hens, and this effect was confirmed in the present study that serum TC contents was decreased by FR supplementation, as well as abdominal fat deposition and sarcous fat.

Lipid peroxidation is a natural phenomenon that has a significant effect on meat quality (Wood et al., 2004). It was reported that lipid peroxidation led to disruption of muscle cell membrane integrity, which may badly induce exudative loss from meat (Buckley et al., 1995). The lipid content is relatively high in broiler chickens, which tends to damage the body through producing ROS. The MDA content is the main end-products of lipid peroxides that generally used as an indicator of an increased oxidative stress in the body (Gaweł et al., 2004), which can endanger the safety of food (Fernandez et al., 1997). Numerous studies have documented that dietary natural antioxidant supplementation can improve meat quality by decreasing lipid peroxidation and improving antioxidative status (Zhao et al., 2018; Salami et al., 2016). It is well known that flavonoids act as antioxidants and free radical scavengers (Procházková et al., 2011). It also has been reported that administration of RA polysaccharides possess effective antioxidant potential, can significantly promote serum and hepatic antioxidant enzyme activities in chicks and rats and decrease lipid peroxidative levels (Xu et al., 2008; Yang et al., 2009; Sun and Wang, 2010; Yan et al., 2010; Deng and $\mathrm{Hu}, 2011)$. In our study, the increased GSH and decreased serum MDA and hepatic ROS may contribute to the potent antioxidative effect of increased dietary total polysaccharides and flavonoids by the modulation of the cellular free radical/antioxidant balance. In addition, elevated T-SOD activities and $\alpha$-TOH contents were observed in the present study. This could be a sparing effect of dietary total polysaccharides and flavonoids, which also might be explained by a more general mechanism of reducing GSH and $\alpha-\mathrm{TOH}$ consumption by reducing the burden of the enzymatic and non-enzymatic antioxidative system.

The Nrf2 binds to the antioxidant response element in the promoter regions of a number of genes encoding for antioxidative enzymes (Zhu et al., 2005). GSH related enzymes, HO-1, SOD and GPx play an important role in antioxidant system. HO-1 is the rate-limiting enzyme of heme decomposition reaction, and the reaction could produce endogenous carbon monoxide, biliverdin, and ferrous ion $\mathrm{Fe}^{2+}$ (Morse et al., 2009). Biliverdin can be converted to bilirubin under the influence of biliverdin 
reductase. Biliverdin and bilirubin are the two most potential of endogenous antioxidants, which are involved in the composition of the defense system against ROS in the body (Chiu et al., 2002). As expected, our results indicated that supplemental of FR in broiler diets can enhance the antioxidant gene expression of Nrf2, HO-1, SOD, and GPx. We only measured the activities of T-SOD in this study, which was in accordance with the gene expression of SOD. So we can not judge the relationship between the expression of antioxidant enzymes-related genes and antioxidant enzymes activities. An in-depth study of the dietary FR effects on broiler antioxidant system is needed in the future.

In the present study, the results of improved $\mathrm{pH}$ and WHC of birds from FR groups may be attributed to a decreased LD production in muscles postmortem (Raj et al., 1990, 1992). Jiang et al. (2007) reported that the inability of muscle cells to rid themselves of metabolic by-products such as LD causes a decrease in $\mathrm{pH}$, and this decrease in $\mathrm{pH}$ can affect WHC. Lower WHC indicated losses in the nutritional value through exudates that were released and this resulted in drier and tougher meat (Dabes, 2001). The present results showed that FR addition reduced the concentration of LD in breast muscles, which suggested that improved antioxidative status of broilers by FR supplementation may protect skeletal muscle cells against metabolic by-products such as LD. A previous study showed that improvements in WHC and $\mathrm{pH}$ development postmortem were due to increased antioxidative status in the chickens (Young et al., 2003). In the present study, the data showed that WHC is consistent with that of $\mathrm{pH}$ values. The improvement of $\mathrm{pH}$ and $\mathrm{WHC}$ must be related to the anti-oxidative status, enhanced antioxidative status and elevated $\alpha-\mathrm{TOH}$ contents, and the sparing effect of dietary total polysaccharides and flavonoids may play a beneficial role. Therefore, the presence of supplemental FR would be expected to reduce meat oxidation and improve meat quality.

\section{CONCLUSION}

Considering the results obtained herein, it can be included that, the use of up to $6 \mathrm{~g} / \mathrm{kg}$ FR products had a positive influence on meat quality and antioxidant capacity. Total flavonoids and polysaccharides were possibly the key compounds responsible for the health-improving effect of the fermentation products.

\section{ACKNOWLEDGMENTS}

This research was financially supported by the National Key Research and Development Program of
China (Project No. 2017YFD0601001), a Project Funded by the Priority Academic Program Development of Jiangsu Higher Education Institutions (PAPD), and the Special Financial Grant from the China Postdoctoral Science Foundation (Grant No. 2016T90605).

\section{Statement of conflict of interest}

The authors declare no conflict of interest.

\section{REFERENCES}

Abdel-Kader, R., Hauptmann, S., Keil, U., Scherping, I., Leuner, K., Eckert, A. and Müller, W.E., 2007. Stabilization of mitochondrial function by Ginkgo biloba extract (EGb 761). Pharmacol. Res., 56: 493502. https://doi.org/10.1016/j.phrs.2007.09.011

Ahmed, S.T., Mun, H.S., Islam, M.M., Ko, S.Y. and Yang, C.J., 2016. Effects of dietary natural and fermented herb combination on growth performance, carcass traits and meat quality in grower-finisher pigs. Meat Sci., 122: 7-15. https:// doi.org/10.1016/j.meatsci.2016.07.016

Asghar, A., Gray, J., Buckley, D., Pearson, A. and Booren, A., 1988. Perspectives on warmed-over flavor. Fd. Technol., 42: 102-108.

AOAC, 2000. Official methods of analysis of the Association of Official Analytical Chemists $\left(17^{\text {th }}\right.$ ed.). The Association of Official Analytical Chemists, Washington, DC.

Aoki, F., Honda, S., Kishida, H., Kitano, M., Arai, N., Tanaka, H., Yokota, S., Nakagawa, K., Asakura, T., Nakai, Y. and Mae, T., 2007. Suppression by licorice flavonoids of abdominal fat accumulation and body weight gain in high-fat diet-induced obese C57BL/6Jmice. Biosci. Biotechnol. Biochem., 71: 206-214. https://doi.org/10.1271/bbb.60463

Bai, K., Huang, Q., Zhang, J., He, J., Zhang, L. and Wang, T., 2017. Supplemental effects of probiotic Bacillus subtilisfmbJ on growth performance, antioxidant capacity, and meat quality of broiler chickens. Poult. Sci., 96: 74-82. https://doi. org/10.3382/ps/pew246

Bourdillon, A., Carrè, B., Conan, L., Francesch, M., Fuentes, M., Huyghebaert, G., Janssen, W.M.M.A., Leclercq, B., Lessire, M., Mcnab, J., Rigoni, M. and Wiseman, J., 1990. European reference method of in vivo determination of metabolisable energy in poultry: Reproducibility, effect of age, comparison with predicted values. Br. Poult. Sci., 31: 567-576. https://doi.org/10.1080/00071669008417287

Bradord, M.M., 1976. A rapid and sensitive method for the quantitation of microgram quantities $o$ 
protein utilizing the principle of protein-dye binding. Anal. Biochem., 72: 248-254. https://doi. org/10.1016/0003-2697(76)90527-3

Buckley, D.J., Morrissey, P.A. and Gray, J.I., 1995. Influence of dietary vitamin $\mathrm{E}$ on the oxidative stability and quality of pig meat. J. Anim. Sci., 73: 3122-3130. https://doi. org/10.2527/1995.73103122x

Cao, F.L., Zhang, X.H., Yu, W.W., Zhao, L.G. and Wang, T., 2012. Effect of feeding Aspergillus niger-fermented Ginkgo biloba leaves on growth performance, meat quality and lipid metabolism in broiler chicks. Poult. Sci., 92: 1210-1221. https:// doi.org/10.3382/ps.2011-01886

Chang, C.C., Yang, M.H., Wen, H.M. and Chern, J.C., 2002. Estimation of total flavonoid content in propolis by two complementary colorimetric methods. J. Fd. Drug Anal., 10: 178-182.

Chen, S., Xing, X.H., Huang, J.J. and Xu, M.S., 2011. Enzyme-assisted extraction of flavonoids from Ginkgo biloba leaves: Improvement effect of flavonol transglycosylation catalyzed by Penicillium decumbens cellulose. Enzyme Microb. Technol., 48: 100-105. https://doi.org/10.1016/j. enzmictec.2010.09.017

Chiu, H., Brittingham, J.A. and Laskin, D.L., 2002. Differential induction of heme oxygenase-1 in macrophages and hepatocytes during acetaminophen-induced hepatotoxicity in the rat: Effects of hemin and biliverdin. Toxicol. appl. Pharmacol., 181: 106-115. https://doi.org/10.1006/ taap.2002.9409

Dabes, A.C., 2001. Propriedades da carne fresca. Rev. Nac. Carne, 25: 32-40.

David, H., Akesson, M. and Nielsen, J., 2003. Reconstruction of the central carbon metabolism of Aspergillus niger. Eur. J. Biochem., 270: 4243-4253. https://doi.org/10.1046/j.1432-1033.2003.03798.x

Deacon, J.W., 2005. Fungal biology (fourth edition). The Bioprospector, 2: 62-70.

Dei, H.K., Rose, S.P., Mackenzie, A.M. and Amarowicz, R., 2008. Growth performance of broiler chickens fed diets containing shea nut (Vitellaria paradoxa, Gaertn.) meal fermented with Aspergillus niger. Poult. Sci., 87: 1773-1778. https://doi.org/10.3382/ ps.2008-00055

Deng, Z.H. and Hu, Q.L., 2011. Effect of Astragalus membranaceus polysaccharides on oxidative damage in skeletal muscle of exhaustive exercise rats. Afr. J. agric. Res., 6: 4086-4090.

Dubois, M., Gilles, K.A., Hamilton, J.K., Rebers, P.A. and Smith, F., 1956. Colorimetric method for determination of sugars and related substances. Anal. Chem., 28: 350-357. https://doi.org/10.1021/ ac60111a017

Ellnain-Wojtaszek, M., Kruczyňski, Z. and Kasprzak, J., 2002. Variations in the free radical scavenging activity of Ginkgo biloba L. leaves in the period of complete development of green leaves to fall of yellow ones. $F d$. Chem., 79: 79-84. https://doi. org/10.1016/S0308-8146(02)00181-4

Fernandez, J., Perezalvarez, J.A. and Fernandezlopez, J.A., 1997. Thiobarbituric acid test for monitoring lipid oxidation in meat. Fd. Chem., 59: 345-353. https://doi.org/10.1016/S0308-8146(96)00114-8

Gawel, S., Wardas, M., Niedworok, E. and Wardas, P., 2004. Malondialdehyde (MDA) as a lipid peroxidation marker. Wiad. Lek., 57: 453-455.

Goh, L.M., Barlow, P.J. and Yong, C.S., 2003. Examination of antioxidant activity of Ginkgo biloba leaf infusions. Fd. Chem., 82: 275-282. https://doi.org/10.1016/S0308-8146(02)00548-4

Grün, I., Clarke, A., Lorenzen, C. and Grun, J.A., 2006. Reducing oxidation of meat. $F d$. Technol., 60: 3643.

Gui, D., Liu, W.B., Shao, X.P. and Xu, W.N., 2010. Effects of different dietary levels of cottonseed meal protein hydrolysate on growth, digestibility, body composition and serum biochemical indices in Crucian carp (Carassius auratus gibelio). Anim. Feed Sci. Tech., 156: 112-120. https://doi. org/10.1016/j.anifeedsci.2010.01.012

Havsteen, B.H., 2002. The biochemistry and medical significance of the flavonoids. Pharmacol. Ther, 96: 67-202. https://doi.org/10.1016/S01637258(02)00298-X

Honda, K., Kamisoyama, H., Tominaga, Y., Yokota, S. and Hasegawa, S., 2009. The molecular mechanism underlying the reduction in abdominal fat accumulation by licorice flavonoid oil in high fat diet-induced obese rats. Anim. Sci. J., 80: 562-569. https://doi.org/10.1111/j.1740-0929.2009.00670.x

Hong, K.L., Lee, C.H. and Kim, S.W., 2004. Aspergillus oryzae GB-107 fermentation improves nutritional quality of food soybeans and feed soybean meals. J. Med. Fd., 7: 430-435. https://doi.org/10.1089/ jmf.2004.7.430

Hsu, C.L. and Yen, G.C., 2007. Effects of flavonoids and phenolic acids on the inhibition of adipogenesis in 3T3-L1 adipocytes. J. Agric. Fd. Chem., 55: 84048410. https://doi.org/10.1021/jf071695r

Hsu, M.F. and Chiang, B.H., 2009. Effect of Bacillus subtilis natto-fermented Radix astragali on collagen production in human skin fibroblasts. Process 
Biochem., 44: 83-90. https://doi.org/10.1016/j. procbio.2008.09.021

Jang, H.D., Kim, H.J., Cho, J.H., Chen, Y.J., Yoo, J.S., Min, B.J., Park, J.C. and Kim, I.H., 2007. Effect of dietary supplementation of fermented wild ginseng culture by products on egg productivity, egg quality, blood characteristics and ginsenoside concentration of yolk in laying hens. Kor. J. Poult. Sci., 34: 271278. https://doi.org/10.5536/KJPS.2007.34.4.271

Jiang, Z.Y., Jiang, S.Q., Lin, Y.C., Xi, P.B., Yu, D.Q. and $\mathrm{Wu}, \mathrm{T} . X ., 2007$. Effects of soybean isoflavone on growth performance, meat quality, and antioxidation in male broilers. Poult. Sci., 86: 1356-1362. https://doi.org/10.1093/ps/86.7.1356

Karami, M., Alimon, A.R. and Goh, Y.M., 2011. Effect of vitamin E, Andrographis paniculata and turmeric as dietary antioxidant supplementation on lipid and color stability of goat meat. Small Rumin. Res., 97: 67-71. https://doi.org/10.1016/j. smallrumres.2011.02.005

Kayden, H.J., Chow, C.K. and Bjornson, L.K., 1973. Spectrophotometric method for determination of tocopherol in red blood cells. J. Lipid Res., 14: 533-540.

Kleijnen, J. and Knipschild, P., 1992. Ginkgo biloba. The Lancet, 340: 1136-1139. https://doi. org/10.1016/0140-6736(92)93158-J

Köse, K. and Doğan, P., 1995. Lipoperoxidation induced by hydrogen peroxide in human erythrocyte membranes. 2. Comparison of the antioxidant effect of Ginkgo biloba extract (EGb 761) with those of water-soluble and lipid-soluble antioxidants. J. Int. Med. Res., 23: 9-18. https://doi. org/10.1177/030006059502300102

Le Bars, P.L., Katz, M.M., Berman, N., Itil, T.M., Freedman, A.M. and Schatzberg, A.F., 1997. A placebo-controlled, double-blind, randomized trial of an extract of Ginkgo biloba for dementia. J. Am. med. Assoc., 278: 1327-1332. https://doi. org/10.1001/jama.1997.03550160047037

Leschine, S.B., 1995. Cellulose degradation in anaerobic enviroments. Annu. Rev. Microbiol., 49: 399-426. https://doi.org/10.1146/annurev. mi.49.100195.002151

Liu, H.W., Gai, F., Gasco, L., Brugiapaglia, A., Lussiana, C., Guo, K.J., Tong, J.M. and Zoccarato, I., 2009. Effects of chestnut tannins on carcass characteristics, meat quality, lipid oxidation and fatty acid composition of rabbits. Meat Sci., 83: 678683. https://doi.org/10.1016/j.meatsci.2009.08.003

Liu, Z.H. and Zeng, S., 2009. Cytotoxicity of ginkgolic acid in HepG2 cells and primary rat hepatocytes.
Toxicol. Lett., 187: 131-136. https://doi. org/10.1016/j.toxlet.2009.02.012

Luciano, G., Monahan, F.J., Vasta, V., Pennisi, P., Bella, M. and Priolo, A., 2009. Lipid and colour stability of meat from lambs fed fresh herbage or concentrate. Meat Sci., 82: 193-199. https://doi. org/10.1016/j.meatsci.2009.01.010

Ma, X.Q., Shi, Q., Duan, J.A., Dong, T.T. and Tsim, K.W., 2002. Chemical analysis of Radix Astragali (Huangqi) in China: A comparison with its adulterants and seasonal variations. J. Agric. Fd. Chem., 50: 4861-4866. https://doi.org/10.1021/ jf0202279

Maitra, I., Marcocci, L., Droy-Lefaix, M.T. and Packer, L., 1995. Peroxyl radical scavenging activity of Ginkgo biloba extract EGb 761. Biochem. Pharmacol., 49: 1649-1655. https://doi. org/10.1016/0006-2952(95)00089-I

Mathivanan, R., Selvaraj, P. and Nanjappan, K., 2006. Feeding of fermented soybean meal on broiler performance. Int. J. Poult. Sci., 5: 868-872. https:// doi.org/10.3923/ijps.2006.868.872

Miyake, Y., Fukumoto, S., Okada, M., Sakaida, K., Nakamura, Y. and Osawa, T., 2005. Antioxidative catechol lignans converted from sesamin and sesaminol triglucoside by culturing with Aspergillus. J. Agric. Fd. Chem., 53: 22-27. https:// doi.org/10.1021/jf048743h

Morse, D., Lin, L., Choi, A.M. and Ryter, S.W., 2009. Heme oxygenase-1, a critical arbitrator of cell death pathways in lung injury and disease. Free Radic. Biol. Med., 47: 1-12. https://doi.org/10.1016/j. freeradbiomed.2009.04.007

Naik, S.R. and Panda, V.S., 2007. Antioxidant and hepatoprotective effects of Ginkgo biloba phytosomes in carbon tetrachloride induced liver injury in rodents. Liver Int., 27: 393-399. https:// doi.org/10.1111/j.1478-3231.2007.01463.x

Naik, S.R., Pilgaonkar, V.W. and Panda, V.S., 2006. Neuropharmacological evaluation of Ginkgo biloba phytosomes in rodents. Phytother. Res., 20: 901-905. https://doi.org/10.1002/ptr.1973

Nakagawa, K., Kishida, H., Arai, N., Nishiyama, T. and Mae, T., 2004. Licorice flavonoids suppress abdominal fat accumulation and increase in blood glucose level in obese diabetic KK-A(y) mice. Biol. Pharm. Bull, 27: 1775-1778. https://doi. org/10.1248/bpb.27.1775

Ng, C.C., Wang, C.Y., Wang, Y.P., Tzeng, W.S. And Shyu, Y.T., 2010. Lactic acid bacterial fermentation on the production of functional antioxidant herbal Anoectochilus formosanus Hayata. J. Biosci. 
Bioeng., 111: 289-293. https://doi.org/10.1016/j. jbiosc.2010.11.011

Nuala, T.M.M., Sean, A.H. And Kerry, J.P., 2006. Comparative addition of rosemary extract and additives on sensory and antioxidant properties of retail packaged beef. Int. J. Fd. Sci. Tech., 42: 1201-1207.

Pietri, S., Maurelli, E., Drieu, K. and Culcasi, M.J., 1997. Cardioprotective and antioxidant effects of the terpenoid constituents of Ginkgo biloba extract (EGb 761). Mol. Cell Cardiol., 29: 733-742. https:// doi.org/10.1006/jmcc.1996.0316

Procházková, D., Boušová, I. and Wilhelmová, N., 2011. Antioxidant and prooxidant properties of flavonoids. Fitoterapia, 82: 513-523. https://doi. org/10.1016/j.fitote.2011.01.018

Raj, A.B.M., Gregory, N.G. And Wilkins, L.J., 1992. Survival rate and carcase downgrading after the stunning of broilers with carbon dioxide-argon mixtures. Vet. Rec., 130: 325-328. https://doi. org/10.1136/vr.130.15.325

Raj, A.B.M., Grey, T.C., Audsely, A.R. and Gregory, N.G., 1990. Effect of electrical and gaseous stunning on the carcase and meat quality of broilers. Br. Poult. Sci., 31: 725-733. https://doi. org/10.1080/00071669008417303

Rao, A.V. and Gurfinkel, D.M., 2000. The bioactivity of saponins: Triterpenoid and steroidal glycosides. Drug Metabol. Drug Interact., 17: 211-235. https:// doi.org/10.1515/DMDI.2000.17.1-4.211

Salami, S., Guinguina, A., Agboola, J., Omede, A., Agbonlahor, E. and Tayyab, U., 2016. In vivo and postmortem effects of feed antioxidants in livestock: A review of the implications on authorization of antioxidant feed additives. Animal, 10: 1375-1390. https://doi.org/10.1017/S1751731115002967

Sarikçioğlu, S.B., Oner, G. and Tercan, E., 2004. Antioxidant effect of EGb 761 on hydrogen peroxide-induced lipoperoxidation of G-6-PD deficient erythrocytes. Phytother. Res., 18: 837840. https://doi.org/10.1002/ptr.1544

Shi, C., Zhao, L., Zhu, B., Li, Q., Yew, D.T., Yao, Z. and $\mathrm{Xu}, \mathrm{J} ., 2$ 2009. Dosage effects of EGb761 on hydrogen peroxide-induced cell death in SH-SY5Y cells. Chem. Biol. Interact., 180: 389-397. https:// doi.org/10.1016/j.cbi.2009.04.008

Singh, G., Marimuthu, P., de-Heluani, C.S. and Catalan, C., 2005. Antimicrobial and antioxidant potentials of essential oil and acetone extract of Myristica fragrans Houtt. (aril part). J. Fd. Sci., 70: 141148. https://doi.org/10.1111/j.1365-2621.2005. tb07105.x
Smith, J.V. and Luo, Y., 2003. Elevation of oxidative free radicals in Alzheimer's disease models can be attenuated by Ginkgo biloba extract EGb 761. J. Alzheimers Dis., 5: 287-300. https://doi. org/10.3233/JAD-2003-5404

Smith, J.V. and Luo, Y., 2004. Studies on molecular mechanisms of Ginkgo biloba extract. Appl. Microbiol. Biotech., 64: 4465-4472.

Sun, H. and Wang, Z.B., 2010. Effects on exercise endurance capacity and antioxidant properties of astragalus membranaceus polysaccharides (APS). J. med. Pl. Res., 4: 982-986.

Verzelloni, E., Tagliazucchi, D. and Conte, A., 2007. Relationship between the antioxidant properties and the phenolic and flavonoid content in traditional balsamic vinegar. Fd. Chem., 105: 564-571. https:// doi.org/10.1016/j.foodchem.2007.04.014

Wang, K.H., Shi, S.R., Dou, T.C. and Sun, H.J., 2009. Effect of a free-range raising system on growth performance, carcass yield, and meat quality of slow-growing chicken. Poult. Sci., 88: 2219-2223. https://doi.org/10.3382/ps.2008-00423

Wood, J.D., Richardson, R.I., Nute, G.R., Fisher, A.V., Campo, M.M., Kasapidou, E., Sheard, P.R. and Enser, M., 2004. Effects of fatty acids on meat quality: A review. Meat Sci., 66: 21-32. https://doi. org/10.1016/S0309-1740(03)00022-6

Xia, Y.C., Li, Y.S., Shen, X.X., Mizu, M., Furuta, T. and Li, C.M., 2017. Effect of dietary supplementation with sugar cane extract on meat quality and oxidative stability in finishing pigs. Animal Nutr., 3: 295-299. https://doi.org/10.1016/j.aninu.2017.05.002

Xu, X.F., Gu, X.L., Luo, Y. and Zhao, M., 2008. Effects of astragalus polysaccharides on antioxidant status of chicks. J. Herbal Med. Toxicol., 2: 45-49.

Yamamoto, M., Saleh, F., Tahir, M., Ohtsuka, A. and Hayashi, K., 2007. The effect of Koji-feed (fermented distillery by-product) on the growth performance and nutrient metabolizability in broiler. Jpn. Poult. Sci., 44: 291-296. https://doi. org/10.2141/jpsa.44.291

Yan, H., Xie, Y.P., Sun, S.G., Sun, X.D., Ren, F.X., Shi, Q.R., Wang, S.H., Zhang, W.D., Li, X.M. and Zhang, J., 2010. Chemical analysis of Astragalus mongholicus polysaccharides and antioxidant activity of the polysaccharides. Carbohydr. Polym., 82: 636-640. https://doi.org/10.1016/j. carbpol.2010.05.026

Yang, W.J., Li, D.P., Li, J.K., Li, M.H., Chen, Y.L. and Zhang, P.Z., 2009. Synergistic antioxidant activities of eight traditional Chinese herb pairs. Biol. Pharm. Bull, 32: 1021-1026. https://doi.org/10.1248/ 
bpb.32.1021

Young, J.F., Stagsted, J., Jensen, S.K., Karlsson, A.H. and Henckel, P., 2003. Ascorbic acid, $\alpha$-tocopherol, and oregano supplements reduce stress-induced deterioration of chicken meat quality. Poult. Sci., 82: 1343-1351. https://doi.org/10.1093/ $\mathrm{ps} / 82.8 .1343$

Yu, W.W., Zhang, X.H., Ahmad, H., Zhao, L.G., Wang, T. and Cao, F.L., 2015. Intestinal absorption function of broiler chicks supplemented with Ginkgo leaves fermented with Bacillus species. Pakistan J. Zool., 47: 479-490.

Zarrouki, B., Pillon, N.J., Kalbacher, E., Soula, H.A., Nia N'Jomen, G., Grand, L., Chambert, S., Geloen, A. and Soulage, C.O., 2010. Cirsimarin, potent antilipogenic flavonoid, decreases fat deposition in mice intra-abdominal adipose tissue. Int. J. Obes. (Lond.), 34: 1566-1575. https://doi.org/10.1038/ ijo. 2010.85

Zhao, J.X., Li, Q., Zhang, R.X., Liu, W.Z., Ren, Y.S., Zhang, C.X. and Zhang, J.X., 2018. Effect of dietary grape pomace on growth performance, meat quality and antioxidant activity in ram lambs. Anim. Feed Sci. Tech., 236: 76-85. https://doi.org/10.1016/j. anifeedsci.2017.12.004

Zhang, X.H., Cao, F.L., Sun, Z.Y., Yu, W.W., Zhao, L.G.,Wang, G.B. and Wang, T., 2012. Effect of feeding Aspergillus niger-fermented Ginkgo biloba-leaves on growth, small intestinal structure and function of broiler chicks. Livest. Sci., 47: 170180. https://doi.org/10.1016/j.livsci.2012.04.018

Zhang, X.H., Sun, Z.Y., Cao, F.L., Ahmad, H., Yang, X.H., Zhao, L.G. and Wang, T., 2015. Effects of dietary supplementation with fermented ginkgo leaves on antioxidant capacity, intestinal morphology and microbial ecology in broiler chicks. Br. Poult. Sci., 56: 370-380. https://doi.org/ 10.1080/00071668.2015.1030590

Zhu, H., Itoh, K., Yamamoto, M., Zweier, J.L. and Li, Y., 2005. Role of Nrf2 signaling in regulation of antioxidants and phase 2 enzymes in cardiac fibroblasts: Protection against reactive oxygen and nitrogen species-induced cell injury. FEBS Lett., 579: 3029-3036. 